\title{
The school as a project for the future: a case study of a new Pataxó village school in Minas Gerais
}

\author{
Karla Cunha Pádua \\ State University of Minas Gerais
}

\begin{abstract}
This article presents reflections of indigenous teachers about the role of the school in a new Pataxó indigenous community settlement in the state of Minas Gerais. The data was collected in "narrative interviews" with teachers from this community who attended the first Intercultural Education for Indigenous Educators (FIEI) course offered by the Federal University at Minas Gerais. In these narratives, both the indigenous school and FIEI are seen as a collective project of and for the community. The school occupies a central position in the articulation between traditional ways of producing knowledge and the formulation of projects for the future.
\end{abstract}

Keywords: Indigenous school; Pataxó teachers; Relation with the territory; Future Projects.

\section{Resumo}

O texto apresenta reflexões de professores/as indígenas sobre o papel da escola, numa nova aldeia Pataxó em Minas Gerais. Os dados foram coletados por meio de "entrevistas narrativas" com professores/as dessa aldeia que participaram do primeiro curso de Formação Intercultural de Educadores Indígenas (FIEI), oferecido pela Universidade Federal de Minas Gerais. Nessas narrativas, a escola e a formação são apresentadas como um projeto coletivo, da e para a comunidade e voltados para a realização de seus 
projetos de futuro. A escola aparece como central na articulação entre modos tradicionais de produzir conhecimento e a formulação de alternativas para projetos futuros.

Palavras-chave: Escola Indígena; Professores/as Pataxó; Relação com o Território; Projetos de Futuro. 


\section{The school as a project for the future: a case study of a new Pataxó village school in Minas Gerais}

Karla Cunha Pádua

\section{Introduction}

My interest in indigenous education began when I met indigenous school teachers from various ethnic groups in Minas Gerais (Xacriabá, Pataxó, Maxacali, Krenak, Aranã, Kaxixó e Xucuru-Kariri) who were the first cohort of students to attend a course on the Intercultural Training of Indigenous Teachers (FIEI) given at the Federal University of Minas Gerais (UFMG). This special undergraduate course, which lasted five years, from 2006 to 2011, was funded by the Support Program for University Education and Intercultural Training Courses for Indigenous Teachers (PROLIND) ${ }^{1}$. Through a specific selection process, all candidates were required to present a recommendation letter written by community representatives and signed by the local leadership as a way of guaranteeing the Indigenous Movement's control over the course. This process resulted in 146 selected students (Pádua 2009; Rezende 2005).

The course was organized in three areas: Language, Arts and Literature; Mathematics and Sciences of Nature and Social Sciences and Humanities. There were three thematic axes: socio-environmental reality; the indigenous school and its participants; and multiple languages. Students joined to one of these areas and axes according to their research

1 In 2009 a new Teachers Training Course was inaugurated with funding from the Federal Universities Reconstruction and Expansion Plan (REUNI), thus transforming the FIEI into a regular undergraduate course with an annual intake of 35 students. (Silva 2012) 
interests and the concerns of their communities, so that each one could follow a specific academic curriculum. The course alternated intensive periods at the UFMG usually in the months of May and September, with periods of time that were preferentially spent in the villages. (UFMG s/d; Pádua 2009)

At that time, I was taking my doctorate degree and I was interested in understanding the repercussions of multiculturalism for Education. The presence of these new actors in the corridors of the university led me to choose them as subjects for my research. ${ }^{2}$. I carried out research based on participant observation during the activities of the FIEI, and during the informality of the break time moments between the classes, I also interviewed various indigenous teachers. But the focus of my research was neither the course nor the teaching process, but rather the transformations in indigenous identities at that particular time they entered the University environment.

In 2012, however, I began new research to analyze the repercussions of the FIEI on the life and the teaching practice of the indigenous teachers after they had finished the course. This time I decided to know the home villages of these pupils. So, I began my field research in a small Pataxó village called Muã Mimatxi ${ }^{3}$, in the municipality of Itapecerica, Minas Gerais whose school had four teachers who had been students of the first FIEI course: Kanatyo, Siwê, Duteran e Sarah. During the month of May 2012, I made long narrative interviews ${ }^{4}$ with these teachers and also with their colleague Liça. During these interviews, they revealed

2 See Pádua 2009.

3 According to Kanatyo, one of the village leaders, this name in Pataxó means "Little Piece of Land" (Pequeno Chão), "Little Forest" (Pequena Mata) or even, "Little part of the Forest" (Pequena Moita de Mata).

4 This type of interview differs from semi-structured interviews by presenting a single question that generates discussion, giving liberty to the people interviewed to construct their own narrative without interference from the interviewer (Flick 2004; Teixeira \& Pádua 2006; Silva \& Pádua 2010). Kanatyo (Salvino dos Santos Braz) is the head of the village, married to Liça and history teacher. During the FIEI he carried out research on "Pataxó culture, identity and tradition", in the area of Social Sciences and Humanities. Liça, (Luciene Alves dos Santos) who is a specialist in traditional knowledge, teaches on "Land Use". She had never been to school. Sarah dos Santos Braz, the head's sister is a young widow with 5 children. She teaches Geography and Portuguese and during the FIEI she carried out research on the histories told by her mother, who is the oldest woman in the community, in the area of Language, Arts and Literature. Duteran Braz Alves is not presently living in the village. He taught Sciences and during the FIEI he researched on the Pataxó language in the area of Language, Arts and Literature. Siwê Alves Braz is the head's son and the youngest of the interviewees. He combines the roles of Coordinator of the school and teacher of mathematics and science. During the FIEI he researched on mathematical games in the area of Mathematics and Sciences of Nature. 
relevant aspects of the conceptions which guide the relationship between the Pataxó people with their school and their teaching training. These narratives expressed a form of collective thinking oriented to their future projects, anchored in a particular context of construction of a new village in Minas Gerais. This article is part of the process whereby I set out to understand this context ${ }^{5}$ in which distinct concepts and practices emerge with regard to education and the school, always in dialogue with multiple influences ${ }^{6}$ and yet "tangled with local thought" (Rappaport e Pacho 2005: 40).

Kanatyo, the tribal chief and a teacher at the indigenous school in the village, reminds us of the need to understand this context, when he affirms that education depends on the needs of each "community," and of each "people," because perhaps what serves one people, does not serve for me, the education for youth of one people, perhaps is not what I want at that time." "The education must be conducted in dialog, according to what the community has as a life plan," he added. For this Pataxó village, what is most important according to Kanatyo is that "the education have a community base," and "have its feet on the ground of the community."

This aspect of education as a demand of the community and for the community was indicated by Arévalo (2010) as a characteristic of the specific modes of producing and reproducing knowledge by the indigenous peoples. It is in this sense that the teachers of the Muã Mimatxi village said that they had sought at the university an intercultural education "which becomes part of our life project," of the "project for a future life" of the village, as Kanatyo emphasized. Sarah, another teacher at the indigenous school in the village emphasized the benefit of the knowledge for her community and for improving collective life, placing herself at its service.

Everything that we learned there, we passed on to the students and also to the community. What we were learning there, what was happening there, did not remain only among the teachers, the knowledge was passed on to everyone and to the students as well [...] The knowledge was not just

5 The research was supported by a grant from CAPES (Coordination for Higher level Graduation Improvements) held at the Instituto de Ciências Sociais of the Universidade de Lisboa, with Susana de Matos Viegas as a my supervisor.

6 About these networks, see Pádua 2014. 
knowledge for within the school, only for the teacher, it was for the entire community. (Sarah)

These connections with the needs and the rhythm of life of the communities were already foreseen in the curriculum proposed in the Intercultural Education for Indigenous Educators course. The student-selection process for the course requested a letter from the communities, signed by the local leader, to guarantee control over the course by part of the indigenous movement (Rezende 2009). It was thus a differentiated selection process, without evaluations of knowledge, in which the presentation of this letter written by representatives of the indigenous community constituted one of the criteria (UFMG 2005). This aspect was emphasized by those interviewed, who also mentioned the implications of the commitment assumed towards the community, as well as the collective responsibility of their education.

At first, like always for all the teachers, for all of us who are indigenous, at least in the group of the Pataxó, when we enter in this means of education as a teacher, the first evaluation is made by the community [...] Thus, I did not nominate myself to go, to take the teacher accreditation course [...] and the education I have had. According to the evaluation that the community makes of us, even if I am a teacher and have been accredited, if I don't please the community, there is no way for them to have me go to UFMG. But, as I said, I was chosen. It's like I said, it begins there, it is the community that chooses the teacher, it is not the teacher who goes. So, since I was chosen, I went there and one of our focuses was [...] that what we got there was to bring and pass on to our community here. (Duteran - teacher in the indigenous school in the Muã Mimatxi village)

[...] It was very difficult' at that time, to leave the small boys, knowing that we also had a responsibility to the community, the students, to give them a good education, to bring to them knowledge from the outside, in addition to what we already have, from here within. So, at that time, it was very difficult for me, but at the same time it was a responsibility that I had to my students, to the community. (Sarah)

7 This teacher referred to her difficulty in leaving the children of the village to study in the Intercultural Education of Indigenous Educators course, which was held twice a year, usually in May and September, in Belo Horizonte. 
But what community does this involve? Who are the Pataxó of the Muã Mimatxi village? We begin by presenting the village, in the way that it was presented to us in the narratives and how we perceived it in the first field contacts.

\section{Rested Earth: the Muã Mimatxi village}

The intercultural education course, in which the Pataxó teachers participated, coincided with a quite specific context in the life of their group: the occupation of a new territory and the creation of a new village in Minas Gerais.

Figure 1 - Localities of indigenous ethnic groups in the state of Minas Gerais and the South of Bahia. Cartography and GIS: José Flávio Morais Castro (PPGG-TIE/PUC Minas), 2015.

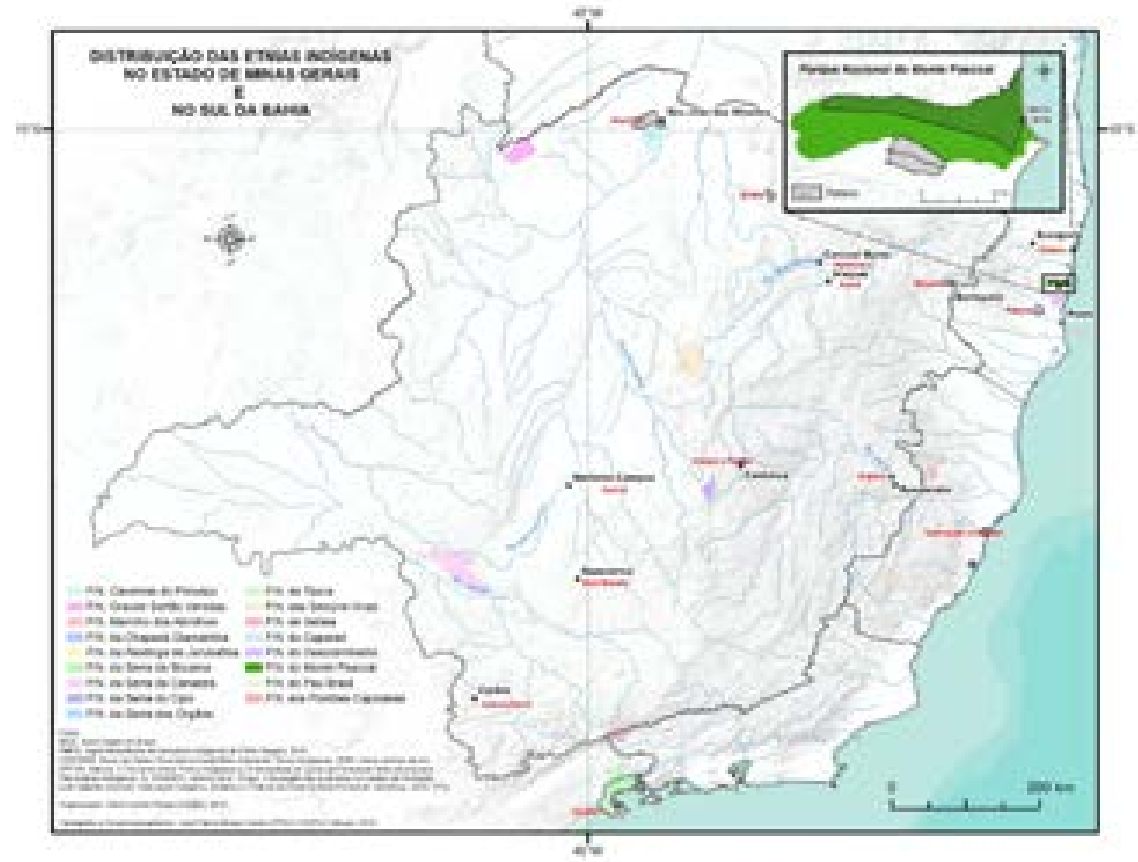

It occupies an area of approximately 145 hectares, according to Kanatyo, located in the municipality of Itapecerica, MG (See Figure 1), quite close to the district of Lamounier. The residents of these towns 
seem to have received the newcomers very well. The people with whom we spoke in the municipality talk about the Indians in the Muã Mimatxi village with respect. They appear in the pamphlets of the municipality as a tourist attraction. At a commemoration in May 2012 of the 1ooth anniversary of Divinópolis, an old district of Itapecerica, attended by various politicians, the Indians were invited to the opening of the event. They lit a torch, danced and sang for the public, presenting Pataxó traditions. In relation to this respect for the Indians, which is different from that found in other regions of the country, where there are serious and violent conflicts involving the struggle for the land, Duteran commented:

We see that here there was no conflict with other people. We came here, the people accepted us well and we thus see that the way that we are working here, various people admire our work and other relatives that went there (to the course) (said), its often not like that.

According to Kanatyo it had been federal government land ${ }^{8}$ that they first shared with squatters, who left the location in October 2011, when they lost a case in court to the Indians. "They left without a problem, we waited until the right moment and they left" said Kanatyo.

The population of the village is made up of approximately 58 Pataxó Indians from 11 families, who belong to the same "line of relatives" (Kohler 2007). Seven of them are school teachers, who offer distinct disciplines $^{9}$ for small groups of students of different ages. There are two entrances to the village. One of them is close to the paved road that links the municipality of Itapecerica to the district of Lamounier. Along the highway there is a sign is somewhat hidden in the middle of the woods with the name of the village, and a gate which is left locked. To enter the village by car visitors must call a resident from the first house, which is located quite close to the entrance, at the bottom of an embankment. ${ }^{10}$

8 According to Carvalho and Miranda (2013), it was land ceded to Funai by the Serviço de Patrimônio da União (Federal Assets Service).

9 In May 2012 there were two teachers of "traditional culture" at the village (of culture, and of land use), four teachers who had studied in the first FIEI and one who was recently approved in the new FIEI.

10 This house is currently unoccupied because the family that lived there moved to another Pataxó village in Minas Gerais, in Carmésia. 
Arriving at this entrance from above, walking along the dirt road, one soon sees the home of the head of the village. It is better constructed than the others and, as we discovered later, it is the only one in the village that has a bathroom, which is shared with two other families. Nearly in front of the chief's house there is a small, simple wattle and daub building, where one of his sons live with his wife and children. Behind the chief's house, a bit closer to the forest that borders the edge of the village from above, lives his other son and his family, in a better house, made of bricks.

On the other side of the small road that runs through the middle of the village lies a swampy area that the squatters had used to plant rice. Liça, who teaches principles of land use ${ }^{11}$ told us that the land was "resting," so that the natural vegetation could return and attract back wild animals. They mention with pride that they have already begun to see paca [a medium-size rodent] and jacu [a large bird in the Penelope genus] in the region, as well as many other bird species. They say that they intend to build a pond for fish in the same area.

The houses in the village are separate from one another and each has a small garden behind where they grow vegetables for their own consumption. Continuing along the road one comes to the center of the village, where the school is located in a new building, with a kitchen, bathroom and three classrooms. The building is clearly the best in the community and the school has become the center of community life, as it has been the case in other indigenous villages, such as the Kaxinauá for example (Weber 2006).

Behind the school, there are more houses and the health clinic, which also occupies a new brick building. Farther back, close to the forest, another teacher from the school lives with her family. Everyone in the village is related to everyone else. Marriage is preferred between cross cousins and prohibited between parallel cousins. Children learn these rules at a very early age.

In this central area, there is a large square, two old run-down buildings, and other small houses, some with wattle and daub walls and dirty

11 A class given by representatives of the community and detainers of traditional knowledge, which does not require specific education. Liça did not study in the Indigenous Educators course, and although it was not in our plans, she spontaneously offered us her narrative, in May 2012. 
floors. On the right side there is a woodland, used for rituals and to exhibit crafts when there is an event at the village.

This central area divides the village into upper and lower halves. In the lower half live the women, including the two oldest in the community. The chief's mother-in-law lives alone in an old masonry house, and in the lower half, the chief's mother and her sister with children live in two quite simple houses. At the entrance to one of the houses there is a spigot covered with a tarp used to wash utensils and bathe the children. The chemical toilets, in large and lengthy metal structures, clash with the scenery. There are many plants around the houses. The oldest woman in the community knows their names and their medicinal properties. Some of the species grown are used in handicrafts, others for cooking, as well as the simple pleasure of trying out new species (Cunha and Almeida 2002).

The second entrance to the village is located below these houses in an area that gives access to another forest and to the river. Close to this second gate there is a small road that leads to neighboring farms and to the district of Lamounier, located a few kilometers away.

During the field research we observed that the children move freely through the village unaccompanied by adults. They play in the dirt, do cartwheels, seem happy and are not very noisy. The animals, (dogs, chickens, a toucan) scamper amid the adults and children and are treated with respect. There is always someone making crafts at the door of their houses. The youth who study in the city flirt with each other on the way home. The younger ones who study in the village school participate attentively and quietly in school activities. When an adult is speaking they pay attention, listening and observing everything.

The peaceful life that we found during this first field visit, in May 2012, did not erase the memories of the difficulties faced at the beginning of the occupation: "we lived here for many days under a tarp, later we went to a big house there, we made a few huts there," Kanatyo explained. We heard stories of the cold and rain that they faced without lodging. One newborn baby, the child of a young couple, died in this initial period of the occupation, but the Indians did not like to discuss this. There are different versions of this event and there is a place in the lower portion of the village, circled by bamboo, with 
a name in the native language, which we learned was where the child was buried.

Despite the friendly relations between neighbors, Kanatyo complained that "the land is small, there is no forest, no river, no game, little hunting, the animals are scarce and small," as well as the lack of support and partnerships to develop projects related to the land. He conplained that "FUNAI is very distant from us." ${ }^{{ }_{12}}$ As we mentioned previously, the territory where they live is truly quite small.

Liça also highlighted that from the traditional Pataxó perspective of knowledge, "the land is completely tired, sick," as are the rivers that run through the village:

I work with this side, with the culture of land, because today, not just here, but in all places, the earth is completely tired, sick. In my time, I did not see ill water, I did not see a sick river, I did not see a sick plant, I did not see sick fruit. Game, fish, everything was healthy, whenever I wanted to work with it I did. Now I live on land that is the government's, [on which] we are building our house.

Here we have no river, we have two rivers, but they are ill. They pass here within this little clump of woods there, tomorrow you will see. The other runs there, and divides the land. They divide the land, on this side is ours. Here too, on the other side, it makes the division. But they are sick.

We see quite a struggle, some support life on the land, others come to destroy it. For this reason the land is like this, moreover we received land that is tired, sick, poisoned.

It is clear that the territory of the village, in addition to being small, has serious ecological problems: polluted rivers, land depleted from previous use that made it "sick" and "poisoned," impeding its productive use. Liça and Kanatyo refer to the degradation of the land as a consequence of

12 The Regional Coordination of FUNAI [the federal Indigenous Foundation] for Minas Gerais and Espírito Santo is located in Governador Valadares and there are five Local Technical Coordinations in the state, in Carmésia, Resplendor, Santa Helena de Minas, São João das Missões and Teófilo Otoni, all located quite far from the Muã Mimatxi village. See: <http://www.funai.gov.br/index.php/coordenacoes-regionais> and <http://www. funai.gov.br/index.php/coord-tecnicas-espirito-santo-minas-gerais> 
the destruction caused by the squatters who lived there previously. The principal attitude of these Pataxó is, however, of a mild optimism, well expressed in the idea of "letting the land rest" so that new life may be reborn. Now they are trying to recuperate, "working hard with this issue of the strength and energy of the land, of plants," seeking "something that is useful for our lives, like a fruit tree" (Kanatyo).

This attitude is strongly articulated to political demands and defense of rights (to land, to healthcare and to education) that the Pataxó teachers of this village take to the Intercultural Education for Indigenous Educators Course. According to Kanatyo, when they reached this territory, "there was nothing, it was land that had squatters here." In addition to a concern for the land, the narratives indicated a concern for the future of new generations, in a context of great proximity with the urban environment.

This was the concern of the leadership, and mine, and is this until today, I still think: What is the plan that we have to develop within the village for our young people? Since our community is small, how will we develop a project for our children and young people? It is based on this thinking that we will try to make this life project, our life plan, because we do not want our children to go there outside and stay outside, we want them to go out and come back to us. (Kanatyo)

All of these issues related to the context of life in the village, according to Kanatyo, are taken to the school for reflection and collective work. They also influence the relationship with the knowledge provided at the Intercultural Education for Indigenous Educators course and with the indigenous and non-indigenous groups with whom they meet during their academic activities.

And we [discovered] the experience of other indigenous peoples speaking of their life on the land, speaking about their struggle, their life, their conquests $[. .$.$] maturing how we could develop this issue of struggle for$ land, because at that time our focus was on land (Kanatyo).

Our understanding is that this interest in exchanging with other Indians and non-Indians is guided by a philosophy of sociality in which history is permanently produced in the relationships with the "other," 
which resignifies the memory and produces new possibilities for the future. Culture, from this perspective, is presented as "a set of potential experiential structurings, capable of supporting a variety of traditional contents and absorbing new ones: it is an acculturating device or one that is constituent of processing of beliefs" (Viveiros de Castro 2002: 209).

To understand this philosophy of sociality, Viegas (2002), also referring to the experience of the Pataxó in regional meetings in Bahia, uses the metaphor of trails that suggests the image of trails cleared in the forest, which lead to other places and relationships, opening creative possibilities and flows of coming and going. According to the author, this philosophy is guided by four principles: 1) the history they share, 2) the connection of human action with the environment, 3) the simultaneity of movement and localization and 4) reversibility. In the narratives of the teachers interviewed, these principles are articulated in constant references to the collective history of the Pataxó, in attempts to recover a type of relationship with the landscape that was lost over time and to expand the social connections with other groups. The school becomes an appropriate space for them to undo past mistakes and imagine new realities.

\section{Memory of the Origins: Between Bahia and Minas Gerais}

The life of my people was like this, they lived going up and down the rivers, when it was hot they were closer to the coast, when it was cold they went to the center of the forest, in the mountains. That's how the life of the people was (Kanátyo Pataxó).13

To understand the relation of this Pataxó group with the school and with the educational process it is necessary to understand the collective history of the Pataxó. Kanatyo refers to their origins when he recalls that:

In the land of our origin [we] were free, we walked all day on the land, there was no fence, you lived where you wanted to live. No one sold, no one bartered, no one was owner of the land, for example, we made a planting here, if I didn't like it or I liked another better, I left that one there, I didn't

13 This statement was collected in the context of my doctoral study. See Pádua (2009: 131). 
sell it, I left it there, with those fruits, those things, another relative would pass by and eat, so it became a "ceveiro" ${ }^{14}$ that attracted people and animals, and the person would go live in another. Life was like that... (Kanatyo).

Today we see that this question has changed, the communities grew, they were growing with more people, and we saw that for us to continue this thinking...Our people is a people that always traveled in small groups...[This is] the reason we are here. We always lived like this.... (Kanatyo).

Kanatyo's narrative relates to a time when the Pataxó moved freely between Bahia and Minas Gerais and to the theme of the constant family migrations through this vast territory, which have been widely registered in the literature (Grunewald 2001; Carvalho 1977; Sampaio 1996; Pádua 2009).

About these peoples, known as Aimoré, and their relations since the colonial past, Dantas, Sampaio and Carvalho (1992) mention that the various peoples of the families Maxacali, Pataxó and of the large family of the Botocudos lived by wandering in small bands through the Atlantic Forest, resisting the conquest of their land for three centuries. According to Sampaio (1996), these people did not live in villages like the Tupi. They established themselves seasonally on the coast to gain access to the rich fauna of the estuaries and mangroves, and then returned to the forests.

Viegas and Paula (2009) also refer to the long distance movements of the "wandering," "untamed" and "wild" Indians with propensity to war, mostly from the Jê family, as the Pataxó, in forests located beyond the Padeiro mountains, in southern Bahia State. These movements have been interrupted, according to the authors, since the 1930s and 1940s, when the land was occupied by Brazilians and transformed into private property.

About the freedom to travel through the land, Duteran also commented that in the past, "the Pataxós always wandered through the forest, like we say, to the center of the earth." He emphasized that in the past, this was possible "because the space was quite big." "Before [they put a child on their back and] left, stayed for a time, went, stopped somewhere, stayed

14 According to the Dicionário Aulete, this term refers to a "place where bait is placed for hunting or fishing". See: <http://aulete.uol.com.br/ceveiro\#ixzz2w5OBp2nH>. It seems to refer to the places with good hunting or fishing that led the Pataxó to temporarily settle in their wanderings through a vast territory, between Bahia and Minas Gerais. 
for a while, until they reached the destination they wanted," which is no longer possible, because the lands are occupied by the farmers. "Today, it is dangerous to stop on the edge of a farm; there are even police afraid to invade the area, so there is no way".

D. Josefa said that in Barra Velha (Ver Figura 1) there is a place that the people gave the name of Céu, because there in Céu was a place to meet other groups who came from the woods to the coast. She said that the Pataxó got mussels at the edge of the beach and would exchange them with the people who came from the forest for fruit, game, tubers. So, they had this encounter and they said that when they came, they shouted, there was only one shout, which they used when they arrived and they said: those are the people who are approaching. So they all got together because they all knew. For example, if it was the group of the Jacaré clans, then they would give a different shout, warning that (it was] they were the ones who were coming. These encounters were frequent. And with the Maxakali, they got together to war against another group as well, against the other groups. Often, when there was a war also of people stronger than the Pataxós, a larger group, the Pataxós would take refuge with the Maxakali, or the Maxakalis would take refuge with the Pataxós, so there was always this union between these two peoples. (Duteran)

The older people remember when there was frequent contact between the Pataxó and the Maxacali, and tell the younger members of the village about it. In fact these two peoples have had regular contact, as indicated by their linguistic and cultural affinities and the presence of these historic relations in the Pataxó oral tradition, as emphasized by Carvalho and Miranda (2013). Grunewald (2001) also highlighted the alliances between the Pataxó, the Maxacali and other small groups in the region from the Jequitinhonha to Mucuri to fight the Botocudos, a process that lasted until the second half of the nineteenth century. ${ }^{15}$

Contradicting Kanatyo, Carvalho (2009) stresses that the Pataxó lived in the forests and usually came down to fish in the mangroves, to exchange forest products for products from the coast and meet Indians from other

15 The bibliographic research presented here on the historical context is important to understand the wider ethno-cultural environment within which the conceptions of the interviewees are formulated. 
ethnicities, considered "relatives", in a flow of exchanges that was only broken with the deforestation of the region (Carvalho 2009). They turned travel into opportunities to create situations of contact and expand relations with "others," beyond economic activities, as suggested by Viegas (2002). They thus lived warring, escaping, exchanging products in the forests of Bahia and Minas Gerais, seasonally shifting to the coast in search of fish, to then once again withdraw to the forests, always following the rivers in these journeys. Barra Velha had been their last refuge (Grunewald 2001).

Carvalho dates the rise of the village of Barra Velha to 1861, when it may have combined different ethnic groups, with the Pataxó and the Maxacali, "the only ones among the various ethnicities existing in the area to survive until the present" (1977: 110). Given their historic affinity, due to a long situation of contact, these two people united once again in a more recent past, as demonstrated by the reports about the "Fire of 51."

The "Fire of 51" and the creation of the Monte Pascoal National Park in 1961, according to Carvalho and Miranda (2013), are related to the migratory movement of the Pataxó of Barra Velha to Minas Gerais. This movement of entire families, such as that of the Kanatyo, is always the fruit of a collective decision, as emphasized by Kohler (2007).

\section{The Fire of 51 and Monte Pascoal National Park}

The indigenous teacher Duteran mentioned in his narrative the episode of the "Fire of 51," that it was related to the migration of the Pataxó from Minas Gerais. In his research into the Pataxó language during the FIEI, he found out about the historical relationships between the Pataxó and the Maxacali, and the connection between the paths between Bahia and Minas Gerais with this event which is deeply rooted in the collective memory of this group and until today is not sufficiently clarified, as emphasized by Carvalho (2009). The Fire of 51 is still an obscure event in which Indians were involved in an assault on a merchant, after they were misled by two men to believe that the merchant had come to resolve a situation of land demarcation, brought about by the creation of the Monte Pascoal National Park (See Figure 1). Residents of Barra Velha village responded strongly against the Pataxó, burning their houses, capturing certain Indians, who 
were subjected to humiliating punishments. Those who were able to flee went into the forest or ended up taking jobs in farms of the region. This traumatic episode marked the temporary disarticulation of the old village of Barra Velha, dispersing the Pataxó for a time, until they gradually returned and met once again at Barra Velha (Kohler 2008; Grunewald 2001; Carvalho 1977).

According to Duteran, the Fire of 51 was responsible for the departure but also the return of the Pataxó to Barra Velha in the period after the incident. He affirms that with the passage of time, some families returned, but because of "pressure from the whites" left once again and "returned after a while." In addition, she affirmed that the Fire of 51 was responsible for the death of many of the elderly, and was remembered as a period in which "our grandparents and great-grandparents became reticent" to say "that they were Indians. So, they fled; all the people there from Barra Velha fled and sought shelter on farms."

Often the farmers even wanted to kill the Indians, abused and killed them, other [farmers] helped, but helped in exchange for work. You work for me and I will hide you here. So, the people were afraid to say; "I am an Indian" and to use the indigenous name as well. In this way they stopped speaking the language and learned to speak Portuguese, to not be identified as an Indian and be killed, because many were hunted at the time. So, for this reason there is this hesitancy to say that one is an Indian, to speak the language, and they left it aside. So, only some people who left and then returned to Barra Velha speak, at times (Duteran).

Kohler (2008: 9) analyzed variations found in the oral versions of the Fire of 51, observing different emphases according to the sociocultural context in which they were produced. Greater difference was found among the versions in Barra Velha, where the dramatic event took place, than those in Itamaraju, which is farther away.

In the oral reports at Barra Velha about the incident, Kohler (2008) found a certain homogeneity, with an emphasis on the humiliation suffered and how the Indians were reduced to the primitive condition of animals, associated to their past as wild Indians, before their Evangelization. About these humiliations, Nayara Pataxó (apud Professores Pataxó 2007: 17) reported: "Mother also said that they ripped 
the scalp of old Júlio and made him eat it, they made him walk and run from the village to Caraíva, running along the beach, goading him, making him run and jump with a harness like a mule.”

After some time, when some families were returning to the village, as in a reported myth, Kohler (2008) reported that the Pataxó began to emphasize their condition as civilized, Catholic, hardworking, honest Indians who fought to conquer their rights, as we can see in the statement below.

It is clearly seen that in Barra Velha, the Indians that survived against wind and tides, who fought and obtained the restitution of their traditional territory, insisted on passing from the undetermined status as foolish, angry, brutish Indians, to that of civilized, hard-working, Catholics, etc. It was a struggle, not only on legal grounds, but also semantically, to be called Indians and no longer caboclos [mestizos], tapuios, and other names that they were given. (Kohler 2008: 9)

The author affirmed that he found among the Pataxó of Barra Velha a certain disdain for the Indians involved in the Fire of 51, because they let themselves be so easily fooled by two men, a situation that would not occur today, given that the Indians are now wiser, and not foolish as they were before. This aspect is also emphasized in a written report on the incident made by an Indian, at the request of a teacher, and transformed into a text to be used pedagogically in the indigenous school at the village of Itamaraju. According to Kohler (2008), this representation coincides with the paternalistic and moralistic vision of the Brazilian Forest Development Institute (IBDF), ${ }^{16}$ who considered the Indians of the past to be ignorant and gullible, incapable of distinguishing between good and bad. This representation, according to Kohler, contaminated this written report that presented the Indians as ignorant and manipulated and therefore, responsible for what happened. Nevertheless, we can interpret the affirmation and valorization of the idea that today they are "civilized" Indians, from another perspective, that is, in the sense that they better understand the society of the "whites," and know how to relate better with their logic.

16 Kohler (2008: 6) is referring here to the reports of the IBDF - now known as IBAMA (The Brazilian Institute for the Environment and Natural Resources) - which, in the late 196os described the living conditions of the Pataxó who live in the area of the Park. 
This interpretation echoes analyses that show the positive valorization of being a civilized Indian - as is the case of the Tupinambá de Olivença (Viegas 2007) or of the Piro of Peru. (Gow 1991).

While the oral tradition of Barra Velha emphasizes differences between the Indians of the past and the present, the written version of Itamaraju, increasingly influenced by the version of the whites, emphasizes the role of a police captain who quelled the rebellion and put an end to the poor treatment inflicted on the Indians. According to Kohler (2008), these different versions of the Fire of 51 show how the struggle for ethnic recognition also takes place on a semantic level, involving the collective rewriting of the past. In the report from Itamaraju, which portrays a white captain as a protector of the Indians and attributes a passive role to the Indians, the introjection of a negative self-image is observed, which Kohler sees exclusively as an influence of the dominant representation from the world of the whites. In the versions of Barra Velha, whose narrators have actively participated in the movement for ethnic affirmation, another vision of the Indians is highlighted, in which they are authors of their own destiny (Kohler 2008).

This episode, according to Carvalho (2009), is related to the creation of the Monte Pascoal National Park which is considered by the author as a critical event that both triggered a process of dispersal of the Pataxó, but also contributed to their ethnic reaffirmation. The Monte Pascoal National Park was created in 1943 as a national monument, by Decree-Law no. 12.729 published in the Diário Oficial government newspaper, to memorialize the discovery of Brazil, preserve flora and fauna and promote tourism. The decree made no reference to the presence of the Pataxó Indians in the area to be demarcated, although their presence in the region has been registered since the seventeenth century (Carvalho 2009).

According to the author, with the demarcation of the area of the park, the state itself triggered an action by the part of the Pataxó community in defense of its interests, which coincide with the period of the 1970s when recognition of ethnic rights was sought (Kohler 2007).

The finalization of the surveying for the delimitation of the area of the park, which took place around 1944, raised concern among the Pataxós. So a leader of the Pataxó community in Barra Velha at the time of the fire, known as Capitão Honório, went to the Indian Protection Service (SPI) 
in Rio de Janeiro [then the national capital], to seek support for defense of the Pataxó lands. Carvalho (2009) mentions that documents were presented to various agencies, including a letter written by Captain Honório. Carvalho relates this fact to the destruction of the village, which occurred one year and ten months after the visit.

This author mentions the political and ideological context of the time, suggesting that the persecution of communist members of the government motivated the uprising that left the local population indisposed towards the Indians and triggered an exaggerated police response. She refers to news articles that linked the two instigators - those who allegedly enticed the Indians with promises of land demarcation - to the Communist Party ${ }^{17}$ or to the Indian Protection Service. In the case of the communists, the presumption was that they represented "a movement of a social character acting in conjunction with rural populations," that is, that it was not a simple assault, but an action with broader intentions (Carvalho 2009: 513). In terms of the Indian Protection Service, the fact that the letter from Captain Honório was lost by the institution is presented as an effort to avoid attention from the agency and to facilitate the action of the two agents, whose motivations remain unclear. The author also mentions similar events that were not clarified that took place in the same year in relation to the Xacriabá people in Minas Gerais, which could be related with those that took place with the Pataxó of Barra Velha.

With the Fire of 51, the "tough repression led to the death of two non-Indian leaders, the prison of the 'captain' and of ten more Indian men and women, and the dispersion of the rest, in utter despair." (Carvalho 2009: 513). In conjunction with the demarcation of the land of the Monte Pascoal National Park, this event motivated the dispersal of the group and intensified its intermingling with the regional population. Since the 1970s, however, the Pataxó began the struggle for recognition of the ancestral right to their traditional territory, resulting in the occupation of the entire area of Monte Pascoal in 1999 (Kohler 2007).

17 The author affirmed, however, that this relationship between the Fire of 51 and the Communist Party is a hypothesis that requires careful verification. It is important to recall that in the 1930 other Indians who defended their own cause were accused of involvement with communists. (Viegas and Paula 2009: 192) 
Sampaio (2000) also associates the implementation of the park, in 1961 , and the prohibition of planting on their own lands with the movement for the dispersal of the Pataxó from Barra Velha.

The author affirms, however, that in the following decades, the struggles over the occupation over the area of the park ended up placing the Pataxó at the historic location of the discovery of Brazil. This transformed the Pataxó - who previously were not recognized as an indigenous people, but as mestiços - into the largest indigenous group in Bahia, with the power to reconquer Monte Pascoal as an indigenous territory.

In the 196os, before the conquest of Monte Pascoal, the Indigenous Protection Service began efforts to raise awareness of the administrators of the National Park so that the Indians could remain on their lands and would have the right to cultivate them, initiating the return of those who had been dispersed. (Carvalho, 2009: 516). In the early 1970s, FUNAI set up an Indigenous Post at Barra Velha and negotiated an agreement with the Brazilian Forest Development Institute so that the Pataxó could plant in the areas of the park where the forest had been cleared in the past (Sampaio 2000). In 1980, the Pataxó won the demarcation of a strip of 8,600 hectares of the park, reinforcing the movement to reunite a portion of the dispersed population. Nevertheless, as Sampaio emphasized, this did not end the impasses generated by the creation of the park.

The agreement between FUNAI and the Brazilian Forestry Institute, which was made without broad consultation of the communities, according to Carvalho's (2009) analysis, was considered harmful to the Indians because it gave them an area of the park composed of sandy swamps while leaving out the mangroves, an important source of Pataxó food. A working group was composed to analyze the situation, resulting in the recognition of the area as indigenous and in the recommendation of its regularization, which was approved in 1991 (Carvalho 2009: 517).

Insatisfaction with this demarcation led to a campaign by the Pataxó for the reconquest of the area of the park, with the support of various indigenous organizations. In 1999, the movement acquired the right to the entire area of Monte Pascoal. Then, new contradictions were established, according to Kohler (2007), with the classification by UNESCO of the park as an ecological reserve. This led to divergent interests between 
the environmentalists and those concerned with the welfare of the indigenous population.

It is important to emphasize that these two episodes of the Fire of 51 and the creation of the Monte Pascoal National Park are remembered as deep historic wounds that accompany the historic trail of the Pataxó and with which they had to struggle, politically and morally, to affirm their right to the traditional territory. The histories narrated by the teachers interviewed for our study indicate their identification with this collective history, and present us the new trails they have taken through Minas Gerais.

\section{Opening New Trails in Minas Gerais}

Before occupying the current territory in the municipality of Itapecerica, the Pataxó of the Muã Mimatxi village who left Barra Velha, passed through the Fazenda Guarani Indigenous Territory, ${ }^{18}$ in the municipality of Carmésia, also in Minas Gerais. According to Grunewald (2001), the Guarani village with 3,270 hectares took shape in the second half of the 1970 s with Pataxó families from Barra Velha, who had lived with Indians of various ethnicities. The Krenak Indians had been living on this old farm that had been used as a prison by the Indigenous Protection Service, to which they were compulsorily transferred, and they only left the area in 1983-1984. Grunevald also claims that Kanatyo's family group moved to Minas Gerais in the 1980 .

Liça, Kanatyo's wife, identifies herself as being a "thorough-bred," Pataxó because she was born in the village of Barra Velha. She affirms that she migrated with her family to Minas Gerais nearly 30 years ago. In a statement from 1998, taken by Valle (2001), Kanatyo told of the movement of her family to Carmésia, in Minas Gerais:

I was born in Barra Velha and I always wanted to get to know more Indians, indigenous nations... I had many relatives of mine living here and I wanted to meet them... there the land was getting smaller... when the IBDF took the Monte Pascoal National Park... there wasn't room for everyone... So the idea arose for me to come here with my family, my parents... my uncle... so

18 This Indigenous Territory - or reserve - was approved on 29/10/1991 (Ricardo 2000: 713). 
we came... then we began to struggle... the land was still not demarcated... we helped in the demarcation... we struggled hard for demarcation [...]. (Kanatyo, apud Valle, 2001, p. 62).

According to Carvalho and Miranda (2013), there are seven Pataxó communities in Minas Gerais, with four of them located at the Fazenda Guarani Indigenous Territory, in the municipality of Carmésia; the Muã Mimatxi village, in the municipality of Itapecerica; Jundiba/Cinta Vermelha, in the municipality of Araçuaí, which is also inhabited by Pankararu and Jeru Tukumã, in Açucena. A total of 349 inhabitants live in these villages in Minas Gerais, of which 246 are at the Fazenda Guarani. There is a movement for the occupation of new lands by groups from the Fazenda Guarani, motivated by "situations of territorial insufficiency and a scarcity of natural resources" (Carvalho and Miranda 2013:3).

In an interview granted in 2012, Kanatyo justified his family's move from Bahia to Minas Gerais, and later from the Fazenda Guarani, in Carmésia, to Itapecerica, as an attempt to preserve the traditional Pataxó way of life. He spoke of the changes that took place in the way of life of the villages, including population growth and the presence of non-Indians, to locate a life plan and a future more in keeping with the Pataxó traditions, that they are tryhing to recover and preserve at the Muã Mimatxi village. This discontentment, like that of Kanatyo, which led many Pataxó families to look for new territory, was expressed by César: ${ }^{19}$

[...] The Guarani is a location, I don't know if you know, various peoples lived there and later went to São Paulo, and only the Pataxó remained and it became a Pataxó village. Except that ten years ago Guarani was going through a very complicated adaptation, with interference from people from the outside, with other ideas arriving and the elders did not adapt to these environments. It is a location that many people go to. There are many people from the outside living inside, they marry with Indians and are living there. The people began not to like this, they said: "ah, I am not going to make my culture for the outsiders to see." So the people did not feel good like that, living inside, wanting to be Indian without having an indigenous identity. And that's how we began to look for a new territory.

19 César is a teacher in the village of Cinta Vermelha/Jundiba, in the municipality of Araçuaí. Interview conducted in February 2013, during the second stage of the study, which took place in this village. 
Cesar and Kanatyo, then, justified their migrations to escape from proximity with non-Indians who they feel threaten the traditional Pataxó way of life, as well as a search for more territorial space. Nevertheless, Kohler (2007) argues that family mobility as an important aspect of Pataxó culture. This author locates the families, understood as a lineage of relatives, as supports for temporality, and above all, of meaning for the Pataxó. From this perspective, each family has a certain location in the territory and can begin a migratory movement.

According to this author, when the tendency does not prevail for the Pataxó to abandon their place of occupation to head for a new family space, with marriages, a family expands its occupation in the space of two or three generations until it forms an entire community. Kohler (2007: 4) even presents the migratory trend as being deeply inscribed in the Pataxó habitus, which resulted from a very old diasporic experience, linked to the movement of catechism that took place in the second half of the 19th century.

The Pataxó's intense family and social mobility, according to Kohler, leads to a conception of places as circuits, routes, itineraries and networks - both diachronic, as well as synchronic - which move the families from one place to another, and at the same time, tell the story of the different steps of family life. This mobility co-exists with the desire to have a home and with a strong appreciation for distinct territories. These apparently conflicting desires do not represent a paradox for the Pataxó.

Another aspect indicated by Kohler (2007) is the economic motivation for the migrations of family groups, given that agricultural production among the Pataxó is conducted by family circuits. These itineraries are established as memories of an entire group, with the support from spatial and temporal references, which have their roots in Barra Velha and whose branches reach the Pataxó villages in Minas Gerais.

The life trajectory mentioned by Duteran relates to the historic trajectories of circulation through the territory, inscribed in the Pataxó way of life. It also points to the permanence of the connection with the mother village, a starting point for the formation of all the others, "the place of the 'trunks,"' or of origin, and a center of diffusion of Pataxó culture, as Grunewald (2001: 79) emphasized. 
I was born in Barra Velha, came to Minas, then returned to Barra Velha and then returned and I am here today. I have lived at Carmésia, now I am living here. I know two Pataxó villages here and I know Barra Velha, which is my true place of origin. ${ }^{20}$

On these non-linear paths and itineraries, forming circuits of coming and going, between Bahia and Minas Gerais, recalling old trails of the past and opening new routes of occupation and adaptation to new places and territories, the Pataxó of the Muã Mimatxi village today use the school to revive their historic memory, which remains fragmented in the stories of the elderly.

In a group whose "historic memory was sadly sacrificed, leaving only tenuous memories that form a quite fragile framework, obtained at the cost of few and fragmentary statements" (Carvalho 1977: 92), the contact with what they call the Socioecological Calender tool at the indigenous educators course provided a rich opportunity to systematize these memories. The school occupies a central place in this process, contributing to the recovery of traditional myths and histories and to the systematization of knowledge once guarded only "in the head" and in the memory of the elderly.

The Socioecological Calendar is a methodology for the organization and presentation of results of the Inductive Intercultural Method, developed by María Bertely Busquets and Jorge Gasché. Based on the revalorization and inclusion of indigenous knowledge and know-how, this tool is part of an alternative curricular proposal for college-level education of indigenous teachers, which has been experimented with since 1988 in countries such as Peru, Mexico and Brazil (Silva 2012; Gasché 2013; Pádua and Veas 2013). It was presented to the teachers in the Muã Mimatxi village during the discipline on Land Use during the FIEI, by researchers of the Observatory of Indigenous School Education (OEEI) of the UFMG.

According to Sarah, the "calendar of life here of the people of the Muã Mimatxi village" is an important point of reference for the pedagogical project for the school. In Siwê's words, it helped "the specific ways of living and working during school hours":

20 In mid 2013, in one of my trips to the village I learned that Duteran's family had moved once again, this time back to Fazenda Guarani, in Carmésia-MG. 
We worked out our own distinct way of living and working during school hours. So, we put these materials together as parameters of the teaching matrix for the children. For example, what we live and what this means for school learning, for us to apply to the children. So we developed our idea. Now, we have a stronger idea of the specific and differentiated education we desire. (Siwê)

During field research, in May 2012, I observed what were called intercultural lessons that involved all the teachers and students in a collective activity to develop a part of the calendar called "Time and Clear Waters", where they drew and told myths and traditional histories they had heard from the communtiy elders. Kanatyo made the following comments about this activity:

[...] One of the projects is the calendar of the world, of living and life, which we are still developing. We are also working with a time that we are going to put into the calendar that is the time we christened and feel that it is the Time of the Clear Waters. After this time, [came the time] of turbulence, the time of 1500 onwards, the time of aggression, of the destruction of nature, of wars, and such like. But we don't want to work with this time just now. We are returning in time to the clear waters, trying to strengthen our spirit, our min, our culture. So we are mapping out this world, this mythical world of the Pataxó. [...] Traditional knowledge comes from there. We are developing these things, making maps. Ever since we were almost finalizing the course, we have been working with this material; trying to exchange experiences and. This is show we are developing our education. The fishbone [of our education], as Márcia Spyer ${ }^{21}$ says, is this calendar that we are working with and with which we will continue to work. [...] Our school is a differentiated school; the teaching materials are being elaborated with the children and also with the community.

The use of drawing as a way of visualizing territorially significant elements in calendars (Bertely 2011) is part of the Inductive Intercultural Method (Método Indutivo Intercultural), which, in the Muã Mimatxi

21 Márcia Spyer was general coordinator of the FIEI and is responsible for many of the innovative ideas that have been put into practice in the curriculum of the course. 
village, is leading to the elaboration of significant educational materials that have recently been published..$^{22}$ This transformation of the results of research undertaken by students and teachers into pedagogical and didactic materials that can give direction to the daily life of the school have been very well received in the village.

Mythical figures linked to traditional histories and that appear in the children's drawings drew our attention to the way in which memory is reconfigured in the dialogue between generations. The theme of the creatures of the forest also appears in an interview conducted by Domingos, the pajé in the village of Cinta Vermelha/Jundiba, in Araçuaí. ${ }^{23}$ He mentioned the vine of the caipora, the father of the forest, the mother of the rock, the mother of the water, the jundiba, the sucuri, the muçum and tupã (thunder), as spiritual entities found in the Pataxó imaginary. According to his statement, these entities belonging to other kingdoms, those of the enchanted, are capable of communicating with them and helping them in many situations.

For Liça the territory also appears to be "enchanted," as for Kanatyo, for whom "our spirits also live there...in nature," as do the ancestors and "the spirits of the elderly of 500 years ago who are present here..." (Kanatyo, cited by Valle 2001: 62).

Kohler (2007) observed the existence, among the Pataxó of Bahia, of a mixture of Catholic beliefs and rituals with elements of enchanted pajelança spirits or those from rural candomblé. In the universe of the pajelança, the character of the wild Indians of the past stand out - the Baquirá24 - imbued with prestige and mystery, who appear as caboclos at the curing ceremonies, invoked and incorporated by the pajé shaman or in the Tore ceremonies, by the participants in the dance. These entities, more present in the ritual universe of men, are perceived as representatives of the ancestral savage world. Their domain is the forest and the rivers,

22 Among publications that resulted from this work and that have been written by indigenous teachers and their students of Muã Mimatxi village, I would mention "Calendar of the times of the the Pataxó village of Muã Mimatxi” (Calendário dos tempos da aldeia Pataxó Mũ̃ Mimatxi) and "The Science of night and day. (A ciência da noite e do dia), both edited in Belo Horizonte: Literaterras-Fale/UFMG, 2012.

23 As we mentioned in note 22, the second phase of the study was conducted at the village of Cinta Vermelha/ Jundiba in February 2013. At this time, although it was not in our plan, Domingos told us various stories that were recorded, with his authorization.

24 Wild Indians who live below the Earth and who can come to the surface in defense of the contemporary Pataxó Indians. 
places of passage of the subterranean world. Where the caboclos and other creatures live like the father of the earth or the caipora, who are representatives of the subterranean kingdoms and the onça pelada, an entity of the forest, representative of the ancestral world, who threatens the humans who go alone into this environment.

The way that this Socioecological Calendar was appropriated and recontextualized in the practices undertaken at the school ${ }^{25}$, appears to find a foundation in this collective history and in the cosmology of the Pataxó. As Kohler indicated (2007), the history of family migrations are very old and rooted cosmological concepts guide the representations of the world and a specific way of thinking about temporality, using spatial categories. In this way, the Socioecological Calendar was adjusted to the concepts of this Pataxó group, allowing the articulation of history and memory with a way of life, in a continuous transformation process (Gallois 2004), placing it at the service of collective demands.

Liça tries to transmit to the new generations these particular modes of relating to the territory, which she affirms are part of the traditional Pataxó culture. She highlights the importance of the school, today, for the transmission of this traditional knowledge and for the register of knowledge, previously stored only in the memories of the older people of the community.

My teaching is more within the traditional culture of the Pataxó people, with the work with the land. So, thus, for me, it is good to work in the school. As we always say, our education is learned in the customs themselves, in the practices, within our own life, our routes in the fields, in the work of the land. We ask the mother and father how they could be dealing with the land, looking at the land, working with it, caring for it. It is learning by fireside, in the history class. It is when one learns looking, doing in practice. So, these were the teachings. But today people bring the teaching inside the school, because [...] we are in another world, in a world different from that [...] of the past. [...] Today, there are other teachings as well, there is written learning, from the school. We only have the writing in our head, like me, I only have it in my head. (Liça). 
This teacher emphasizes that today, the new generations live in the world "of writing, of the pencil, of the pen" and for this reason it is necessary to articulate the oral knowledge and the practice of traditional culture with that of the school. Since she only stores the knowledge "in her head," in school she teaches with drawing and research (walking, looking, observing): "I look for the design there and take it and explain it to them. We do it in the field as well, we clean the space of the village." Liça considers the "teaching" of the school to be good, because it registers "this traditional Pataxó way of life," "because many things today are disappearing, are also ending and the culture (can) disappear as well." For Liça, education in the school is a way of "not letting our customs die."

There are some people who think: "why should the Indians want so much land since they do nothing?" But we will do a lot if we get the land from here as far as Belo Horizonte. As far as I am concerned, there is much that I will do, because I will live on it so I will not want to destroy it. The land will remain alive, if only we could go back in time, I would leave everything new again. When I am really old, or my friends who arrive, they will see. We want land for planting, for hunting, for collecting, not for destruction. This marsh here provided much rice, people were able to harvest so much rice. It was good for them, but for me it is better than it is now. [...] Ah, there is so much that I see here, grass, plants for medicine. There are frogs, insects and there are many rodents. I could even get my food from there. I wouldn't eat the rice, but I would eat some wildlife and my medicine. (Liça)

Liça's narrative reveals some concepts that guide the relationship of the Pataxó at the Muã Mimatxi village with the territory where they live and their attempts to relate the routes of tradition with the future of new generations in work conducted at school. They tell us that the relationship of the Indians with the land is poorly understood, because "we want land to plant, we want land to hunt, gather, and not to destroy." This is different from the squatters, who depleted the land by planting so much rice. The Pataxó prefer to let the area of the "marsh" recover to bring back the animals (frogs, insects, guinea pigs) and the plants "to make medicine." They also presents us the desire to recover the "vital breath" and the "principle of fertility" (Albert 2000) of the land, by means of activities that stimulate research as a permanent practice, capable of producing 
new social relations and at the same time guaranteeing their social reproduction, as it is evidenced by the following:

Here there are small spaces for us to plant manioc, because an Indian is like that: he plants to eat, not to be able to have lots to sell. It is to eat and leave for the animals in the ground. For this reason, we always say, we always teach, that we plant what we eat, what the animals eat, that we plant for ourselves and the animals. My teaching was this care for the earth, the insects, the plants, what does not serve us, serves the animals, the fruits, the seeds, there is nothing that is wasted in the world and in nature (Liça).

Notions of care and of protection for the earth stand out that are quite different from the utilitarian, productivist and predatory logic of the "whites." The narrative is close to that of Davi Kopenawa, in which the universe is thought of as a "social totality guided by a complex system of symbolic exchanges between human and non-human subjects" (Albert 2000: 257). In this type of cosmology, nature is presented as a living entity inhabited by spirits and guardians. In the lessons that we observed, the pupils of all ages were activity interested and seemd to share the school project that had been developed by their teachers. Even so, it will be necessary to continue our research to find out the extent to which the conceptions of the leadership are shared by new generations.

As it can be seen, the school presents itself as a new space for learning, and plays, as it does for many other indigenous peoples, including the Kaxinawá (Weber 2006), an important role in reviving the "culture," at a time in which there is a movement against the devaluation of traditional culture with the intensification of contact. The school is also seen as a way to earn a living for the teachers of the village, but it is above all valued as territory appropriated by them for the elaboration of their future projects, the realization of which depends on the acquisition of tools valued in the world of the whites, like writing.

Liça's narrative also points to the presence among them of a more practical concept of knowledge, which articulates the recognition and systematization of traditional practices of living with the territory with 
the formulation of new perspectives for other modes of living. The school, in this perspective, becomes a space for the transmission of practical knowledge while also linked to daily life and at the same time, for the preparation of local alternatives for the use of territory and of support for the new generations.

\section{Conclusion}

As we saw, the Pataxó history is a constituent part of the routes of this Pataxó group that, today at the Muã Mimatxi village, found the school and transformed it into a project for the future. In Lica's narrative, conceptions of territoriality constructed in these historic routes become fundamental links in the development of life projects at the village, in which the school occupies a central place as an articulator of the dialogue between this historical memory and the construction of the present and of the future of the community. Through the school, the teachers of the Muã Mimatxi village hope to re-establish the relationship with the past and with the landscape and produce new realities that guarantee the survival of new generations. Among many other functions, they hope that the school will help them to value, systematize and transmit to the youngest people the traditional understandings about the relationship with the territory that interlink various dimensions of community life, in dialog with the traditional knowledge of the elders.

Today, everything is through what? Through teaching, education in the school. We see lots of struggle, some for the life of the land, others come and destroy. This is why the land is like this, especially we who received a tired, sick, poisoned land. So, for us knowledge is also very good, it teaches us to care for insects, to not use poison, to not destroy what one has, to help what we have and what we also can be retributing to nature as well. It is also because they [the non-Indians] no longer see life like this, they are destroying, polluting the waters, putting poison in the earth, digging the earth and more earth with machines, tractors...To know how to maintain our culture. Our culture is to preserve the earth more. When we got here, there was only garbage, this entire space was full of garbage. So we got it and went cleaning, the teachers themselves, cleaning and encouraging the boys as 
well to not do these things, to preserve what we have. And I think this is very good! (Liça)

Emphasized in this way in Liça's narrative, the school today represents one more step in the life trails of the Pataxó in Minas Gerais, an appropriated and reappropriated space that nourishes these people's affinity for a relationship with new knowledge and experiences and that gives potential to the continuous movement of elaborating new syntheses and giving origin to new creations. I refer to all that the school and all it social relations make possible, especially all that emergs from the process of intercultural training. For these teachers, the act of teaching seems to mean acquiring and understanding the point of view of others in order to develop new elements for incorporation and re-signifying. From this perspective, the relationship with the knowledge of "whites" that comes with the school, activates transformations and produces new arrangements that the pupils "orchestrate" themselves. (Pádua 2009).

Liça's statements synthesize the idea that the school is a project for the future, seen as central for reactivating relationships with the territory, conceived in the "tradition," as a living entity that is inhabited by spirits and guardians. (Albert 2000). For this reason she suggests exercising practical activities that articulate the dimensions of study, observation, and experimentation to the dimensions of reasoning, speculation and intuition, as emphasized by Cunha and Almeida (2002). From this perspective, research stands out as a guiding process that articulates the minute and detailed observation of what is seen and heard (Cunha and Almeida 2002), which allows them to conduct experiments, which are understood to be crucial to maintaining, transmitting and expanding knowledge. Our research suggests that these teachers give great value to a kind of practical knowledge, for example, when we are clearing or working the land as Liça said, but also when research results in products such as game, calendars, maps etc.

In this way, at this historic moment, the school presents itself as one more opened trail, which allows them to articulate memory, a relationship with the landscape, expansion of connections with alterity and open, malleable concepts, and in a continuous process of transformation. Carrying in memory their life trails from the past, rising and descending the rivers, this Pataxó group from the Muã Mimatxi village now opens new trails 
towards the school, in the expectation of constructing a new future. In the words of Kanatyo, "the school today is our forest, our river, our mangrove" (Pádua 2014), and a source of memory and self-sustainment, a special place for generating fruits that will guarantee their social reproduction and the future of new generations. For this to take place, however, it is necessary to balance knowledges "from here and there" (Sarah), knowledge from the village and from the world, "fishing" from the intercultural collaboration those elements that best adapt to the conceptions and demands of collective life.

Received 8 November, 2014, approved 2 April, 2015

Translated by Jeffrey Hoff.

Revision and copydesk, Peter Fry

\section{References}

ARÉVALO, Libio Palechor. 2010. "Epistemología e investigación indígena desde lo propio". Revista Guatemalteca de Educación, 2(3): 195-227.

Disponível em: $<$ http://wikiguate.com.gt/pdf/Epistemologia_e_invindi. pdf> Acesso em: 11. Mai. 2012.

ALBERT, Bruce. 2000. "O ouro canibal e a queda do céu: uma crítica xamânica da economia política da natureza (Yanomami)”. In: Bruce Albert e Alcida Rita Ramos (orgs.), Pacificando o branco: cosmologias do contato no Norte-Amazônico. São Paulo: Editora UNESP. pp. 239-274. BERTELY, María Busquets. 2011. "Aprendizajes, (inter) aprendizajes, (re) aprendizajes y (des) aprendizajes al tejer una red de cuatro puntas. De cómo se vive la Interculturalidad al pescar conocimientos y significados indígenas y comunitarios." In: (coord.), Interaprendizajes entre Indígenas: de cómo las y los educadores pescan conocimientos y significados comunitarios en contextos interculturales. México: Universidad Pedagógica Nacional - Red de Educación Inductiva Intercultural (REDIIN), pp. 9-38. 
CARVALHO, Maria Rosário de. 1977. Os Pataxó de Barra Velha: seu subsistema econômico. Dissertação de Mestrado, Universidade Federal da Bahia Salvador. 2009. "O Monte Pascoal, os índios Pataxó e a luta pelo reconhecimento étnico". Caderno CRH, 22(55): 507-521. .; MIRANDA, Sarah. 2013. "Pataxó”. In: Instituto Socioambiental (org.), Enciclopédia dos povos indígenas no Brasil. Disponível em: <http:/|pib. socioambiental.org/pt/povo/pataxo>. Acesso em: 06. Nov. 2013.

CUNHA, Manuela Carneiro; ALMEIDA, Mauro Barbosa. 2002. “Introdução”. In: . (orgs.), Enciclopédia da Floresta. São Paulo: Companhia das Letras. pp. 11-28.

DANTAS, Beatriz G.; SAMPAIO, José Augusto L.; CARVALHO, Maria Rosário G. 1992. "Os povos indígenas no nordeste brasileiro: um esboço histórico”. In: M. C. da Cunha (org.), História dos índios no Brasil. São Paulo: Companhia das Letras/Secretaria Municipal de Cultura/ FAPESP. pp. 381-396.

FLICK, Uwe. 2004. "As narrativas como dados”. In: Uma introdução à pesquisa qualitativa. 2a. ed. Porto Alegre: Bookman. pp. 109-123. GALLOIS, Dominique Tilkin. 2004. “Terras ocupadas? Territórios? Territorialidades?”. In: F. Ricardo (org.), Terras Indígenas e Unidades de Conservação da Natureza: o desafio das sobreposições territoriais. São Paulo: Instituto Socioambiental. pp. 37-41. Disponível em: $\leq$ http://pib. socioambiental.org/files/file/PIB_institucional/dgallois-1.pdf $>$ Acesso em: 10. Nov. 2013.

GASCHÉ, Jorge Suess. 2013. "Éxitos y fracasos de una propuesta educativa basada sobre el 'Método Inductivo Intercultural' e implementada en el Perú, México y el Brasil”. Revista ISEES, 13: 17-31. Disponível em: <http:/| www.isees.org/file.aspx?id=7620>Acesso em: 07.Out. 2013.

GOW, Peter. 1991. Of mixed blood: kinship and history in Peruvian Amazonia. Oxford: Oxford University Press.

GRUNEWALD, Rodrigo de Azeredo. 2001. Os índios do descobrimento: tradição e turismo. Rio de Janeiro: Contra Capa Livraria.

KOHLER, Florent. 2007. "Le monde sauvage et la terre des ancetres: les Pataxó du Mont Pascal (Bahia, Brésil)”. Nuevo Mundo Mundos Nuevos, 
Coloquios, [Online]. Disponível em: <http://nuevomundo.revues. org/12822. Consultado 28 Janeiro 2012>. Acesso em: 15. Jul. 2013. . 2008. "Um cordel indígena: história dos dois ladrões que obrigou os índios robar." HAL Archive ouverte pluridisciplinaire, 1: 1-11. Disponível em: <http://halshs.archivesouvertes.fr/docs/oo/26/36/89/PDF/Cordel_ Florent_Kohler.pdf $>$ Acesso em: 7. Ago. 2013.

PÁDUA, Karla Cunha. 2009. "Pegando as frutinhas que estão melhor para comer": afirmação de diferenças e transformações culturais em contextos de formação de educadores indígenas. Tese de Doutorado, Faculdade de Educação, Universidade Federal de Minas Gerais - Belo Horizonte. . 2014. “Nossa mata, nosso rio, nosso mangue': a escola em narrativas de professores/as indígenas”. Rev. Educação em Foco, 17(23): 125-150. _; VEAS, Maria Regina Lins Brandão. 2013. "Recorrido académico e interculturalidad en la formación de educadores indígenas". Revista ISEES, 13: 35-50. Disponível em: <http://www.isees.org/file. aspx?id=7620> Acesso em: 03. Out. 2013.

PROFESSORES Pataxó do Extremo Sul da Bahia. 2007. Uma história de resistência Pataxó. Salvador: Associação Nacional de Ação Indígena/ CESI.

RAPPAPORT, Joanne; PACHO, Abelardo Ramos. 2005. "Una historia colaborativa: retos para el diálogo indígena-académico”. Historia Crítica, 29: 39-62.

REZENDE, Luisa Andrade Lobo de. 2009. "When a university opens itself to diversity: a brief report on the Intercultural Formation Course for Indigenous Teachers, from the Federal University of Minas Gerais (UFMG), Brazil”. Intercultural Education, 20 (3): 203-210. Disponível em: <http://dx.doi.org/10.1080/14675980903138483> Acesso em: 08. Out. 2013.

RICARDO, Carlos Alberto. 2000. Povos indígenas do Brasil, 1999-2000. São Paulo: Instituto Socioambiental.

SAMPAIO, José Augusto Laranjeiras. 200o. "Pataxó: retomadas na rota do quinto centenário”. In: C. A. Ricardo (org.), Povos indígenas do Brasil 1996/200o. São Paulo: Instituto Sociambiental. pp. 715-721.

SAMPAIO, José Augusto Laranjeiras. 1996. Relatório circunstanciado de identificação e delimitação da Terra Indígena Coroa Vermelha. Brasília: FUNAI. 
SILVA, L. J. 2012. "El método inductivo intercultural y el calendario socioecológico como estrategias para el fortalecimiento de una formación crítica e intercultural de professores indígenas de los estados de Minas Gerais y Bahia, Brasil”. Revista ISEES, 10: 79-94. SILVA, Santuza Amorim; PÁDUA, Karla Cunha. 2010. "Explorando narrativas: algumas reflexões sobre suas possibilidades na pesquisa". In: R. C. Campos (org.), Pesquisa, educação e formação humana: nos trilhos da história. Belo Horizonte: Autêntica. pp. 105-126.

TEIXEIRA, Inês A. de Castro; PÁDUA, Karla Cunha. 2006. "Virtualidades e alcances da entrevista narrativa". In: Anais do Congresso Internacional sobre Pesquisa (auto) Biográfica, II. Salvador: UNEB. 1 CD-ROM. pp. 1-10.

UFMG. Projeto Pedagógico do curso. Curso de educação básica indígena: Formação Intercultural de Professor - FIEI. Disponível em: $<$ https:/| www2.ufmg.br/prograd/prograd/Pro-Reitoria-de-Graduacao/Cursos/ Humanas/Educacao-Basica-Indigena-Formacao-Intercultural-deProfessor-FIEI>. Acesso em: 08 out. 2012.

. Notícias da UFMG. 2005. Seminário debate desafios da graduação para educadores indígenas. 14. Dez. Disponível em: <https:||www.ufmg.br| online/arquivos/002773.shtml> Acesso em: 08. Fev. 2015.

VALLE, Cláudia Netto do. 2001. "Txopai Itohã: mito fundador pataxó”. Acta Scientiarum, 23 (1): 61-68. Disponível em: <http://www.periodicos.uem. br/ojs/index.php/ActaSciHumanSocSci/article/viewFile/2734/1882> Acesso em: 20. Nov. 2013.

VIEGAS, Susana de Matos. 2002. "Trilhas: território e identidade entre os índios do sul da Bahia/Brasil”. In: M. I. Ramalho e A. S. Ribeiro (orgs.), Entre ser e estar: raizes, percursos e discursos da identidade, v. VIII, Parte I. Porto: Afrontamento. pp. 185-211. _. 2007. Terra calada: os Tupinambá na Mata Atlântica do Sul da Bahia. Rio de Janeiro: 7 Letras. .; PAULA, Jorge Luiz de Paula. 2009. Relatório circunstanciado de identificação e delimitação da Terra Indígena Tupinambá de Olivença. Brasília: FUNAI.

VIVEIROS DE CASTRO, Eduardo. 2002. "O mármore e a murta: sobre a inconstância da alma selvagem”. In: A inconstância da alma selvagem 
e outros ensaios de antropologia. São Paulo: Cosac \& Naify. pp. 183264.

WEBER, Ingrid. 2006. Um copo de cultura: os Huni Kuin (Kaxinawá) do Rio Humaitá e a escola. Rio Branco: EDUFAC.

\section{Karla Cunha Pádua}

State University of Minas Gerais

kcpadua@yahoo.com.br 